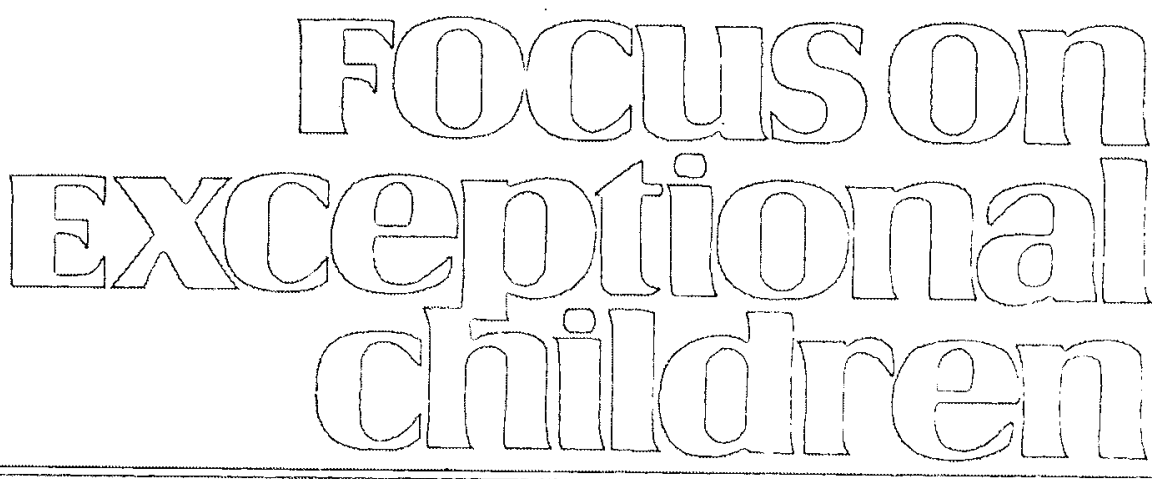

\title{
Effective Writing Instruction for Students Who Have Writing Difficulties
}

\author{
Tanya Santangelo and Natalie G. Olinghouse
}

\begin{abstract}
Writing well is not just an option for young people-it is a necessity. Along with reading comprehension, writing skill is a predictor of academic success and a basic requirement for participation in civic life and in the global economy. Yet every year in the United States large numbers of adolescents graduate from high school unable to write at the basic levels required by colleges or employers... Because the definition of literacy includes both reading and writing skills, poor writing proficiency should be recognized as an intrinsic part of this national literacy crisis. (Graham \& Perin, 2007b, p. 3)
\end{abstract}

As Graham and Perin (2007b) assert, the ability to compose represents a fundamental and essential competency for children and adults alike. Writing is one of the most powerful tools we have for learning and for demonstrating what we know. Therefore, difficulties with writing create significant barriers in education, employment, and other life pursuits (Graham, 2006b).

Despite the importance of writing, assessment data indicate that we are not yet highly effective at helping students gain the critical knowledge and skills required for competent narrative, expository, and persuasive prose. For example, according to the 2007 National Assessment of Educational Progress (NAEP), only 33\% of eighth graders and $24 \%$ of 12th-graders were classified as proficient writers (Salahu-Din, Persky, \& Miller, 2008). The NAEP data further documented that students with disabilities are at particularly high risk for writing difficulties, as the percentage of eighth- and 12th-grade students with disabilities classified as "proficient" writers was $6 \%$ and $5 \%$, respectively (see Graham \& Harris, 2003, for a review of research related to writing difficulties among students with disabilities).

In this article, we offer a synthesis of contemporary qualitative and quantitative research related to one of the most critical elements vis-à-vis improving struggling writers' performance: effective writing instruction. To facilitate understanding and implementation of the findings from what is, indeed, a substantial body of literature, we have organized our discussion into four overarching recommendations:

1. Establish the context for effective writing instruction.

2. Use research-based instructional methods and practices.

3. Teach writing strategies.

4. Teach word-, sentence-, and paragraph-level skills.

Tanya Santangelo is an associate professor in the Department of Education at Arcadia University, and Natalie Olinghouse is an assistant professor in the Department of Educational Psychology at the University of Connecticut. 
Although the ideas and research presented in these four categories have some commonality and overlap, we have chosen to discuss them separately to enhance clarity and utility.

\section{ESTABLISH THE CONTEXT FOR EFFECTIVE WRITING INSTRUCTION}

Recommendations for effective writing instruction are often central to specific content and methods that improve students' compositional abilities (e.g., Graham \& Perrin, 2007a, 2007b). Obviously, this information is critical, and it will be a focus in this article. Research has consistently shown, moreover, that additional factors influence students' writing development, and the impact is especially significant and meaningful for struggling writers (Alvermann, 2003; Graham, Harris, \& Larsen, 2001; Graves, Gersten, \& Haager, 2004; Klinger, Sorrels, \& Barrera, 2007; Pressley, Mohan, Fingeret, Reffitt, \& Raphael-Bogaert, 2007; Taylor, Pearson, Clark, \& Walpole, 2000). Those deemed most salient include:

- teachers' positive beliefs about writing;

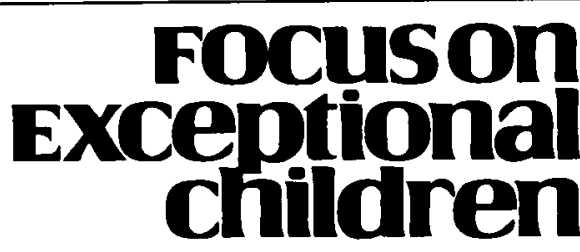

ISSN 0015-511X

FOCUS ON EXCEPTIONAL CHILDREN (USPS 203-360) is published monthly except June, July, and August as a service to teachers, special educators, curriculum specialists, administrators, and those concerned with the special education of exceptional children. This publication is annotated and indexed by the ERIC Clearinghouse on Handicapped and Gifted Children for publication in the monthly Current Index to Journals in Education (CIJE) and the quarterly index, Exceptional Children Education Resources (ECER). The full text of Focus on Exceptional Children is also available in the electronic versions of the Education Index. It is also available in microfilm from Serials Acquisitions, National Archive Publishing Company, P.O. Box 998, Ann Arbor, MI 48106-0998. Subscription rates: individual, $\$ 48$ per year; institutions, \$66 per year. Copyright @ 2009 , Love Publishing Company. All rights reserved. Reproduction in whole or part without written permission is prohibited. Printed in the United States of America. Periodical postage is paid at Denver, Colorado. POSTMASTER: Send address changes to:

Love Publishing Company

Executive and Editorial Office P.O. Box 22353

Denver, Colorado 80222

Telephone (303) 22 1-7333

\section{CONSULTING EDITORS}

Steve Graham Vanderbilt University
Ron Nelson

University of Nebraska-Lincoln

Eva Horn

University of Kansas

Carrie E. Watterson

Senior Editor
Stanley F. Love

Publisher
- establishing and maintaining high expectations;

- attending to the physical environment of the classroom;

- creating a collaborative community of writers, fostering a positive and supportive climate;

- devoting significant time to writing instruclion and practice; and

- optimizing writing instruction.

Together, we conceptualize these factors as the context for effective writing instruction. Their importance cannot be overemphasized, as each is relevant and necessary for every struggling writer. Of course, the way they are realized will (and should) vary based on the specific population and setting-for instance, a first-grade general education classroom compared to a high school self-contained setting. The fundamental principles, however, are universal and should be considered nonnegotiable for educators who are committed to optimizing struggling writers' development.

\section{Teachers' Beliefs About Writing}

Teachers' personal beliefs about writing are the core from which decisions about the role of writing within the curriculum and the nature of writing instruction emanate. As Bruning and Horn (2000) explain:

\begin{abstract}
If teachers' experiences with writing are narrow-gauge, socially isolating, evaluation oriented, and anxiety provoking, they are very unlikely to be able to create positive motivational conditions for their students' writing. On the other hand, if teachers see writing as a critical tool for intellectual and social development and as serving a broad range of important student aims-for cognitive stimulation and growth, self-expression, or social affiliation-lhey will provide settings aimed at fostering similar beliefs. (pp. 30)
\end{abstract}

Thus, highly effective writing teachers not surprisingly are truly passionate about writing, and their classrooms are imbued with that belief (Perin, 2007; Pressley, Mohan, \& Fingeret, et al., 2007). They emphasize the value of writing and underscore that it can be difficult but also exciting and fun. Highly effective writing teachers discuss the myriad ways in which writing is integrated into their own lives. They also frequently share with their students samples of texts they have authored, making sure that the works represent a variety of genres, purposes, and stages of development.

Recognizing that students' lived experiences often do not mirror the teachers' own experiences, effective teachers are cognizant of the need to provide all students-and especially struggling writers-opportunities to explore and share how various forms of composition fit into their daily lives and those of the lives of their family and community members (Ball, 2006; Pajares \& Valiante, 2006; Smith \& Wihelm, 2002). Highly effective writing teachers also work 
to develop struggling writers' appreciation for ways in which writing will help them achieve their future goals.

Unfortunately, results from a recent national survey of primary-grade teachers suggest that these practices are the exception rather than the norm (Cutler \& Graham, 2008). Respondents only moderately agreed that they liked to write and teach writing, and they reported that neither modeling enjoyment or love of writing nor teachers sharing their own writing were frequently occurring practices in the classroom.

\section{High Expectations}

The admonition to "establish high expectations for all students" has become at once trite and ubiquitous in today's educational discourse. A conspicuous demarcation between highly effective writing teachers and their less effective colleagues, however, is the extent to which this goal is endorsed and internalized for struggling writers (Denton, Foorman, \& Mathes, 2003; Pressley, Gaskins, Solic, \& Collins, 2006; Pressley, Mohan, Raphael, \& Fingeret, 2007; Pressley, Raphael, Gallagher, \& DiBella, 2004; Taylor et al., 2000).

Highly effective writing teachers viscerally believe that all students-regardless of culture, socioeconomic status, background experiences, gender, or disability-possess a multitude of strengths and are capable of growth (Ball, 2006; Graham et al., 2001; Tatum, 2008). In addition, these teachers conceptualize students' current ways of thinking and communicating as fertile ground for fostering capacity, as opposed to problems to be eliminated or deficits to be remedied (Villegas \& Lucas, 2002). Through this context, high expectations are established, communicated, and achieved.

The description of what highly effective writing teachers at Bennett Woods Elementary School expect of their students (Pressley, Mohan, Raphael, et al., 2007) provides an illustration of coordinated growth from one grade to the next. By the end of Grade 1, all students are expected to compose multiple-sentence and illustrated responses to what they read (e.g., "What can you infer about the nature of the main character based on the text?"). They use a simple rubric to check and edit their work. In Grade 2, the expectations for compositional length and variety increase. By midyear, all students create multi-page topical books containing one sentence per page. As the year progresses, they compose paragraphs, letlers for correspondence, and, eventually, page-length responses to text. In each instance, the composing process involves brainstorming ideas, drafting text, and using a rubric to revise and edit. In Grade 3 , the expectations for writing processes and products continue to escalate.

For example, in conjunction with a unit on the relationship of living things, all students produce a substantive report about an animal. This project spans several weeks and requires that students first research their animal (i.e., locate and search multiple books for information, take notes, and organize ideas), and then plan, draft, revise (with a rubric), and word-process each of the eight sections that will comprise their final report. While composing, all students must attend to word choice and variety, sentence fluency, paragraph cohesion, the inclusion of specific details, and writing conventions.

Although establishing high expectations for struggling writers is critical, highly effective writing teachers recognize that these goals will be realized only through their subsequent pedagogy; thus, you might say that highly effective writing teachers establish concurrent high expectations for their students and themselves (Denton et al., 2003; Pressley et al., 2004; Pressley, Yokoi, Rankin, Wharton-McDonald, \& Mistretta, 1997; Taylor et al., 2000). Driven by a "no excuses" philosophy, highly effective writing teachers vigorously and relentlessly pursue their goal of ensuring success for every student, especially those who are having difficulties.

When students do not make adequate progress, these teachers engage in critical self-reflection to determine what changes they need to make in themselves to accelerate students' growth. For instance, they might ask themselves, "What can I do differently to help Shanika learn to write a cohesive paragraph?" The creativity, commitment, sense of urgency, and problem-solving skills of highly effective writing teachers enable them to overcome the barriers they encounter. A distinctly different approach is observed among less effective writing teachers, who often rationalize that certain factors are beyond their control and will prohibit some students from making adequate progress. Such a teacher might conclude, "Given Shanika's disability, there's no way she'll ever be able to write a cohesive paragraph," without examining his or her own instructional practices or putting forth the effort needed to produce significant changes.

\section{Physical Environment}

Highly effective writing teachers recognize that the physical environment of the classroom can facilitate students' writing motivation and development (Pressley et al., 2004, 2006; Pressley, Mohan, Fingeret, et al., 2007; Pressley, Mohan, Raphael, \& Fingeret, 2007). Their class libraries are expansive in both breadih and depth. They include an abundant collection of quality literature representing diverse genres, reading levels, topics, and cultures, as well as class- and student-authored works, such as big-books, screenplays, topical resource guides, and poetry anthologies. The classrooms of highly effective writing leachers also are well stocked with a variety of enticing writing supplies. In these 
print-rich environments, proficient and struggling writers alike are actively using books and writing materials interspersed throughout the classroom (Pressley, Mohan, Raphael, \& Fingeret, 2007, p. 227).

Another hallmark of the classrooms of highly effective writing teachers is the pervasive, prominent showcasing of students' writing (Pressley, Mohan, Fingeret, et al., 2007; Pressley et al., 2004). Thoughtfully assembled displays of student work adorn the hallways, walls, and bulletin boards-sometimes they are even fancifully suspended from the ceiling! Importantly, every student's paper is included in each collection. Contrasting the classrooms of highly effective and less effective writing teachers, Pressley, Mohan, Fingeret, et al. (2007) aptly proclaimed, "The writing is on the wall!" (p. 16).

Finally, highly effective writing teachers furnish and arrange their classrooms to be conducive to learning (Pressley et al., 2006; Pressley, Mohan, Fingeret, et al., 2007; Pressley, Mohan, Raphael, \& Fingeret, 2007). For instance, they ensure that all students have a variety of options for working comfortably, such as at a desk, in a beanbag chair, on a couch, and at a table. These teachers arrange (and in some cases, frequently rearrange) the furniture to support multiple instructional formats, such as whole-class discussions, small-group instruction, cooperative learning, and independent work. Often, they also create enticing areas in the classroom to encourage composition (e.g., Poets Corner, Writers' Nook).

\section{Collaborative Community of Writers}

Highly effective writing teachers recognize the many benefits of creating a collaborative community of writers, especially for struggling writers (e.g., Bruning \& Horn, 2000; Pressley et al., 1997; Pritchard \& Honeycutt, 2006, 2007). Embedding writing within a social context enhances students' motivation because they authentically experience, and thus come to appreciate, its communicative purposes (Hidi \& Boscolo, 2006). Because well-structured collaborative writing activities allow students to learn from each other, compositional quality improves significantly (Graham \& Perrin, 2007a, 2007b). And participation in a collaborative writing community promotes cooperation and inclusiveness among students with diverse learning needs and cultural backgrounds (Ball, 2006; Pressley et al., 2001; Pressley, Mohan, Fingeret et al., 2007).

Writing teachers who are highly effective employ a wide repertoire of strategies to establish, nurture, and sustain collaborative communities of writers. For instance, they find creative and engaging ways to promote the social and communicative functions of writing as part of students' daily routines. In an elementary school, this was realized by creating a postal system in which each classroom had its own address and the students were in charge of processing and delivering the inter- and intra-classroom mail (Dolezal, Welsh, Pressley, \& Vincent, 2003). Highly effective writing teachers also provide students with frequent, well-structured opportunities to work together as they plan, draft, revise, edit, and publish (Pressley et al., 2004; Pritchard \& Honeycutt, 2007). Likewise, they engage students in activities that require collaborative planning, drafting, and revising to achieve a common objective, such as creating advertisements for a school event, publishing a monthly classroom newsletter, and developing a literacy-focused class website (Boscolo \& Gelati, 2007). The Freedom Writers and Gruwell (1999) offer a powerful example of how this kind of collaborative writing can be a transformative experience for struggling writers.

Highly effective writing teachers understand that facilitating peer support is also fundamental to a collaborative community of writers (Bruning \& Horn, 2000; Graham \& Harris, 2005; Pressley et al., 1997, 2001). This often begins with an inquiry and discussion of the importance of recognizing classmates' writing efforts and accomplishments and how this can be done effectively. Soon thereafter, the classroom discourse is replete with peer encouragement, reinforcement, and affirmation while students compose. Providing students with more formal and structured opportunities to support each other is also advantageous (Pressley et al., 2004; Pritchard \& Honeycut, 2007). Post-writing activities, such as reading from the author's chair, creating montages, staging performances, and organizing writers community celebrations, allow students to share their work, receive recognition, generate ideas for future texts, and engender motivation.

\section{Positive and Supportive Climate}

A growing body of research documents the importance of creating a positive and supportive classroom climate (Alder, 2002; Alvermann, 2003; Stuhlman \& Pianta, 2009; Tatum, 2008). Thus, it is not surprising that Pressley et al. (2001) found that the classrooms of highly effective writing teachers were "all exceptionally positive places... [We] rarely observed even single moments that were not handled positively and constructively" (p. 46). In stark contrast, many of the less effective teachers' classrooms were "decidedly not positive places for many of the students in them, ones filled with voiced teacher criticisms of students." Moreover, classroom climates are often disproportionately negative for students with learning and behavioral difficulties (Montague \& Rinaldi, 2001).

Caring, respectful student-teacher relationships are the essence of a positive and supportive climate and have been shown to be particularly important for promoting engagement and achievement among students from culturally and 
linguistically diverse backgrounds and students with disabilities (Alder, 2002; Ball, 2006; Bruning \& Horn, 2000; Klinger et al., 2007; Tatum, 2008). Highly effective writing teachers typically initiate the development of relationships in a dynamic pursuit to understand and connect with each student (Pressley, Mohan, Raphael, \& Fingeret, 2007; Villegas \& Lucas, 2002). Far exceeding a review of test scores or cumulative file documents, this process involves gathering data from multiple sources to answer questions such as:

- What are each student's strengths and areas of need in general and with writing in particular?

- What are each student's interests in and outside of school?

- What are each student's future goals?

- How does each student's past schooling experience contribute to his or her current beliefs about writing and writing instruction?

- What role does writing play in each student's daily life, family, and community?

Throughout the year, highly effective writing teachers strengthen their relationships with students by, for example, attending students' extracurricular activities (e.g., a football game or piano recital), reaching out to students' families and communities, creating supplemental opportunities for support and interaction (e.g., Early Bird Writers before school, Chat-and-Chew tutoring during lunch, and Young Poets Society after school), sharing information and stories about their own lives, and encouraging students to talk freely about their personal joys and challenges (Moje \& Hinchman, 2004; Pressley et al., 2004).

Collectively, these efforts yield benefits for struggling writers that are both numerous and significant. Teachers' robust understanding of students' strengths, needs, and interests allows them to design instruction in ways that directly connect writing to students' lives and that build bridges between students' preexisting competencies and those still to be learned (Alvermann, 2003; Ball, 2006; Graves et al., 2004; Pressley et al., 2004; Pressley, Mohan, Raphael, et al., 2007). This is particularly important in light of the finding that, although many struggling writers have an aversion for and difficulty with academic writing as it often is presented in school (e.g., a multi-paragraph response to a prompt), they commonly compose successfully in other ways outside of school (Schultz, 2002; Smith \& Wilhelm, 2002).

Also, knowledge of their students' self-perceptions and attitudes about writing allows teachers to address struggling writers' negativity (Graham et al., 2001; Pajares \& Valiante, 2006; Pritchard \& Honeycutt, 2007). Finally, struggling writers who know that their teachers trust, respect, and care about them are more likely to be engaged, work hard, and persist in the face of difficulty (Alvermann, 2003; Moje \& Hinchman, 2004; Pressley et al., 2004, 2006).

In addition to developing relationships with students, highly effective writing teachers frequently use encouragement and reinforcement to create a positive, supportive climate for struggling writers (Pressley et al., 1997, 2006; Pressley, Mohan, Fingeret, et al., 2007). To be sure, they devote as much, if not more, energy to offer thoughtful, specific positive feedback (e.g., "I' $m$ extremely impressed with how you included details to support that idea..." and "I really like how you took a risk by...") than they do to identify errors and explain areas for improvement (Bruning \& Horn, 2000).

Recognizing that students' writing self-perceptions have a significant impact on both molivation and performance, highly effective writing teachers foster the development of an "I can do this if I try!" attitude (Graham \& Harris, 2005; Pajares \& Valiante, 2006; Pressley et al., 1997, 2001, 2004). This is achieved by reinforcing students consistently for putting forth their best effort (e.g., "Give yourself a pat on the back for working so hard on this story!"), for persevering with challenging and frustrating tasks (e.g., "I know you're frustrated right now; writing definitely takes a lot of thought and effort, and I'm really proud of you for sticking with it"), and for using the knowledge, skills, and strategies they were taught (e.g., "Look at how much you wrote today by concentrating and using your strategy!").

Highly effective teachers further reinforce struggling writers' effort and persistence by constructing instruction as iterative opportunities for learning and improvement rather than a finite, "you've had your one chance" approach (Bruning \& Horn, 2000; Pressley et al., 2006; Pressley, Mohan, Raphael, \& Fingeret, 2007). Consequently, they might tell students, "Yesterday didn't seem to be our best effort, but today's a new day when we can make it up and surge forward," and, "I' $m$ not convinced that this essay represents your best work. I'd like you to work with me and devote some more time and effort so it's something you can be proud of." Epitomizing the impact of these efforts is a student's explanation that highly effective teachers "uplift the spirits of students to help them know they can do anything if they put their heart, mind, and soul into it" (Pressley et al., 2004, p. 226).

\section{Time for Writing}

Struggling writers' realization of high expectations is tied inextricably to the amount of time they spend learning about and practicing writing (Denton et al., 2003; Pressley et al., 2004, 2006; Pressley, Mohan, Raphael, \& Fingeret, 2007; 
Taylor et al., 2000). This is emphasized by Pressley, Mohan, Fingeret, et al.'s (2007) conclusion:

\begin{abstract}
If there is one generalization about writing in our work, it is that in classrooms and schools with good writing, there is a lot of writing instruction from teachers who are passionate about it... [It] was not unusual for 40 minutes or more of language arts instruction to be dedicated to writing in these classrooms. That instruction is complemented by writing at other times of the day, from journal writing first thing in the morning to writing as a part of social studies and science instruction. Writing also occurs in the context of larger classroom projects. (p. 18)
\end{abstract}

Unfortunately, too little time is spent in writing instruction and practice, and balance is lacking in teaching writing strategies, skills, and processes (e.g., Graham \& Harris, 1997; Moats, Foorman, \& Taylor, 2006). In the typical elementary classroom, approximately one hour a day is devoted to writing instruction (Cutler \& Graham, 2008; Graham, Harris, Fink-Chorzempa, \& MacArthur, 2003). Half of that time is spent teaching basic writing skills (e.g., handwriting, spelling, grammar), and close to 15 minutes a day teaching grammar, an instructional practice that has been associated with little to no benefits on writing performance (e.g., Andrews et al., 2006; see also Graham \& Perin, 2007b, p. 21). Teachers report including instruction in planning and revising strategies only 9 minutes a day (Cutler \& Graham, 2008).

In secondary classrooms, writing assignments frequently consist of writing that requires little analysis, interpretation, or actual composing (i.e., short answers, worksheets, summarizing; Applebee \& Langer, 2006; Kiuhara, Graham, \& Hawken, 2009). Accordingly, secondary writing instruction infrequently addresses planning, revising, and editing strategies. In a survey of teens, nearly $80 \%$ reported the average length of their writing assignments as less than one page, and a majority believed that teachers should allow them more time to write to help them improve their writing abilities (Lenhart, Arafeh, Smith, \& Macgill, 2008).

Studies and surveys of exceptional schools and teachers reveal an inattention to writing throughout the day, including writing across the curriculum (Langer, 2001; Pressley et al., 1997, 2004, 2006; Pressley, Mohan, Raphael, Fingeret, 2007; Rankin-Erickson \& Pressley, 2000). When students write in content areas, they gain valuable writing practice, along with enhancing their content learning. Several studies have indicated that writing-to-learn is equally effective across science, social studies, and mathematics content (Graham \& Perin, 2007a, 2007b). In addition to frequent writing opportunities, students in effective schools and classrooms are involved in various forms of writing throughout their school year. This includes writing in various genres and text formats.

\section{Optimizing Writing Instruction}

Highly effective writing teachers recognize that time devoted to writing and writing instruction is a necessary but insufficient condition for success, especially for struggling writers (Graham \& Harris, 1997). Research suggests that highly effective writing teachers optimize instruction by devoting significant time and effort to planning and preparation, maintaining a brisk pace and focus during instruction, balancing explicit teaching with extended opportunities for composing, and differentiating instruction.

"Robust" and "thoughtful" are two words that characterize the instructional planning behavior of highly effective writing teachers (Pressley et al., 2004, 2006). Their comprehensive lesson plans delineate an appropriately sequenced series of relevant learning experiences; each is designed to promote engagement, understanding, higher order processing, and strategic behavior (e.g., drafting a well-structured, authentic composition, as opposed to filling out workbook pages containing decontextualized, lower level questions) (Pressley et al., 2004; Pressley, Mohan, Fingeret, et al., 2007; Vaughn, Gersten, \& Chard, 2000). Moreover, highly effective writing teachers assemble and prepare all necessary resources and supplies prior to teaching so they can be accessed and distributed readily (Pressley et al., 2006).

Highly effective writing teachers maintain a brisk instructional pace and remain on task from the time students enter the classroom until they depart (Denton et al., 2003; Phillips, Fuchs, Fuchs, \& Hamlett, 1996; Pressley et al., 2004, 2006). Consequently, their students are actively engaged in consequential learning experiences more than $90 \%$ of the time (Pressley, Mohan, Fingeret, et al., 2007). For comparison, Taylor et al. (2000) reported that the average on-task percentages for students in highly, moderately, and least accomplished teachers' classrooms were $96 \%, 84 \%$, and $61 \%$, respectively.

Another cornerstone of the instruction of highly effective writing teachers is its eclecticism. That is, they purposefully and thoughtfully integrate explicit and systematic teaching of essential writing knowledge, skills, and strategies with extended compositional opportunities that allow students to authentically apply what they are learning and get feedback (Denton et al., 2003; Graham \& Harris, 1997, 2005; Graves et al., 2004; Pressley et al., 1997, 2001, 2004, 2006; Pressley, Mohan, Fingeret, et al., 2007; Pressley, Mohan, Raphael, and Fingeret, 2007; Taylor et al., 2000; Vaughn et al., 2000).

Within the larger context of learning to write a persuasive essay, for example, a highly effective writing teacher might provide explicit instruction in several relevant and timely aspects of composing in general and of persuasive writing in particular. After the students have completed a draft version of a persuasive essay, the teacher would provide instruction 
on how to construct a powerful conclusion by first reading a few exemplars to the class and then leading students in a discussion of the critical attributes.

Next, students would be given several other examples, working in cooperative groups to decide which ones were strong and which were weak. Using an interactive whiteboard, the teacher then would display a student's persuasive essay draft (with his or her permission, of course) and interactively model how to revise the text, emphasizing how the conclusion could be reworded to be more convincing to the reader.

Finally, students would work with a partner to revise their own persuasive essay drafts. Congruous with research suggesting that it is neither desirable nor necessary to wait until students master lower level skills before engaging them in activities that require higher order thinking (see Perin, 2007), this balanced approach is particularly beneficial to struggling writers. It allows them to receive necessary explicit, intensive instruction and engage in the kinds of composition that, unfortunately, often are reserved for proficient writers.

Finally, highly effective writing teachers recognize that one-size-fits-all instruction-even if it is eclectically balanced-significantly compromises the likelihood that struggling writers will be able to realize high expectations (Graham \& Harris, 2005; Graham et al., 2001; Phillips et al., 1996; Vaughn et al., 2000). Frequent and effective differentiation is a fundamental element of highly effective writing instruction for all students and especially for struggling writers (Graves et al., 2004; Pressley et al., 1997, 2001, 2004, 2006; Pressley, Mohan, Raphael, and Fingeret, 2007; Taylor et al., 2000). Highly effective writing teachers proactively consider how differentiation can optimize struggling writers' success and integrate those ideas into their lesson plans.

For example, if a teacher determines that Sarah, Kyle, Lucy, and Dayvon did not master a previously introduced topic, subsequent lesson plans would purposefully feature small-group reinstruction and supplemental guided practice for those four students. Differentiation can also occur in response to teachers' continual monitoring of students' progress. For instance, if the class was in the process of drafting a story and the teacher noticed that Raphael and Jin were trying to include dialogue in their text but were having difficulty doing so, a targeted, impromptu mini-lesson could be offered to those two students, along with any other interested students.

Describing all the strategies that highly effective writing teachers use to support efficacious differentiation could easily consume the remainder of this article! Therefore, we next provide an illustrative list of strategies that are evidenced-based (Bruning \& Horn, 2000; Graham et al., 2001; Pressley et al., 1997, 2001, 2004, 2006; Pressley, Mohan,
Fingeret, et al., 2007; Pressley, Mohan, Raphael, \& Fingeret, 2007; Vaughn et al., 2000):

- Provide additional explicit teaching and modeling for students who have difficulty acquiring and applying the necessary writing knowledge, skills, and strategies.

- Tailor the content of instruction to meet each student's needs (e.g., teach a simple planning strategy to students who either skip or experience difficulty with planning, and teach a more sophisticated planning strategy for those who have mastered the basics already).

- Provide targeted, opportunistic instruction in response to students' progress and needs (e.g., a mini-lesson on how to add supportive details).

- Control the difficulty of writing tasks to ensure that each student is working on something that is personally challenging but achievable.

- Use a variety of procedural facilitators to support each student's ability to complete writing assignments successfully (e.g., cue cards, think sheets, graphic organizers, mnemonics, and prompts).

- During guided practice, consistently and carefully monitor students' progress and provide feedback and scaffolding in response to individual needs (e.g., when students encounter difficulty, use verbal prompting and other supports in ways that encourage them to think through the task and figure out what to do, rather than telling them exactly how to proceed).

- Recognizing that the amount of time individual students require to compose varies, ensure that each student receives ample opportunity to complete the stages of the writing process successfully.

\section{USE RESEARCH-BASED INSTRUCTIONAL METHODS AND PRACTICES}

Struggling writers often lack knowledge about what constitutes good writing and the writing process (Englert, Raphael, Fear, \& Anderson, 1988; Saddler \& Graham, 2007). For example, struggling writers may view the purpose of writing as producing a neat composition with good spelling but not recognize the higher order writing components such as organization and effective communication. In addition, these students often utilize a writing approach that minimizes or eliminates the writing process (Englert et al., 1988; Graham \& Harris, 1997), which can result in impoverished ideas for writing, shorter written text, disorganized compositions, and surface edits rather than revisions that improve writing quality substantially (e.g., Graham, 1990, 1997).

Because of their writing difficulties, students may lack the motivation to write and, therefore, avoid writing in both personal and school contexts. Accordingly, highly effective writing teachers use research-based instructional methods, 
activities, and tasks that promote students' ability to understand how to access, select, and use writing knowledge, skills, and strategies. In addition, highly effective teachers choose methods, activities, and tasks that will be motivating for students.

\section{Process Writing Approach}

In today's schools, one prevalent method for teaching writing is the process approach. This approach emphasizes that writers learn by doing; that is, writers develop deeper, more complete understandings about the act of composition and their own ideas by engaging in frequent writing opportunities (e.g., Pritchard \& Honeycutt, 2006, 2007). These opportunities revolve around real audiences and authentic writing experiences; students are encouraged to take personal responsibility for their writing projects. Daily writing is embedded in a recursive process of planning, drafting, revising, and editing with many opportunities for sharing and conferencing with both the teacher and peers. Process writing approaches are built upon a belief that different writers have different needs and, therefore, teachers must plan accordingly.

In theory, the process writing approach meets many struggling writers' needs. For example, students are taught that writing is a recursive process, which helps struggling writers engage more fully in the writing process. It provides ample opportunities for differentiation; teachers can plan smallgroup instruction targeting specific learning needs. The process writing approach allows students to work at different paces so slower writers can take the time they need to complete their writing. In practice, however, implementation of process writing approaches is variable (e.g., Lipson, Mosenthal, Daniels, \& Woodside-Jiron, 2000; Pritchard \& Honeycutt, 2006; Troia, Lin, Monroe, \& Cohen, 2009). Therefore, professional development may be necessary for optimal implementation of process-oriented writing approaches (see Graham \& Perin, 2007a, 2007b). Teachers who have not participated in formal professional development may have little or no impact on improving their students' writing.

The efficacy of process writing approaches as the primary instructional approach for struggling writers has been questioned. A meta-analysis (Sandmel \& Graham, 2009) found that process writing approaches did not produce statistically significant effect sizes for students with disabilities or English Language Learners in grades 1-12. Troia et al. (2009) found that the Writing Workshop did not close gaps between grade 4 good and poor writers and that poor writers did not improve their writing quality significantly in portfolio samples.

To make process writing approaches more effective for struggling writers, it is recommended that teachers explicitly teach planning, revising, and editing strategies (especially using Self-Regulated Strategy Development, a model that will be discussed extensively under the heading "Teach
Writing Strategies") within the process writing approach (e.g., Graham \& Harris, 1997). An excellent example of this is given in Harris and Graham (1996), and suggestions for merging Writing Workshop and strategy instruction for primary-grade students can be found in Olinghouse and Kauffman (in press). In addition, process writing approaches often do not address aspects of writing such as handwriting, spelling, and sentence construction; therefore, highly effective teachers develop complete writing programs that include all areas of writing.

\section{Cognitive Strategy Approaches}

Another prevalent method for teaching writing is cognitive strategy instruction, which addresses not only what a student is taught but also how a student is taught (e.g., Graham \& Harris, 2003, 2005; Harris, Graham, Mason, \& Friedlander, 2008). Cognitive strategy instruction includes explicit and systematic instruction, direct instruction, scaffolding, and modeling. In writing, students learn specific strategies for writing and also "how a person thinks and acts when planning, executing, and evaluating performance on a task and its outcomes" (Schumaker \& Deshler, 1992, p. 22). Many writing strategies address aspects of planning, drafting, revising, and editing; therefore, students with writing difficulties receive support to engage more fully in writing. In addition, the self-regulation and metacognitive aspects of cognitive strategy instruction boost knowledge of good writing and the writing process.

Effective strategy instruction empowers students to be active constructors of learning. As teachers transfer responsibility for strategy use to students, the students learn to construct and individualize their own strategy use. Research has demonstrated that a cognitive strategy approach to writing can be particularly powerful for struggling writers, and, accordingly, we provide an in-depth discussion of strategy instruction under the heading "Teach Writing Strategies."

\section{Other Research-Based Practices}

Regardless of the method of writing instruction in a classroom, a number of research-based practices can be embedded in any writing program. These include teaching students how to gather ideas before writing, engaging in inquiry activities, providing good models of writing, setting goals for students to reach in their writing, promoting engagement through the selection of thoughtful writing activities, and using technology.

\section{Pre-Writing Activities}

Highly effective teachers incorporate a number of different pre-writing activities to support the generation and organization of ideas - an area that is often troublesome for 
struggling writers (Graham, 1990, 2006b). Pre-writing and planning activities are critical components of the writing process; however, struggling writers tend to minimize or eliminate planning before writing. When they do plan, their plans often appear as first drafts of their writing. Young writers and many struggling writers generate text in what is called a "knowledge-telling" approach (Bereiter \& Scardamalia, 1987), in which the writers probe their memory for relevant content, transcribe the retrieved content, and then probe again. Rhetorical or personal goals for writing are ignored, and a recursive process of organizing, developing, and reflecting before and during writing is nonexistent.

Explicit instruction in planning and pre-writing, however, can be highly effective for younger and struggling writers. Several planning strategies have been shown to increase the length and quality of students' writing as well as improve the organizational structure of the composition (e.g., Wong, Butler, Ficzere, \& Kuperis, 1996, 1997; see Graham, 2006a and Graham \& Harris, 2003, for reviews).

To encourage the generation of ideas, highly effective writing teachers lead students in brainstorming activities or using graphic organizers (e.g., webbing or mapping activities). Several pre-writing organization strategies can support struggling writers during this phase of writing (see Harris et al., 2008). For example, C-SPACE prompts students to think about the Characters, Setting, Purpose, Action, Conclusion, and Ending of a story before writing. This strategy supports students as they gather and organize their ideas before writing, with an end goal of a more complete and cohesive story.

Students can also read text to gather possible information for their writing. Struggling learners may need explicit instruction in how to use knowledge gained from reading to inform their writing, as they may have difficulty otherwise (Olinghouse \& Compton, 2009). One research-based method to combine reading and writing instruction in content areas is TWA + PLANS (Mason, Snyder, Sukhram, \& Kedem, 2006). In this strategy, TWA prompts students to Think before reading, While reading, and After reading. A set of prompts for each step helps students focus on the text's essential information to use in their writing. Once students are ready to write, PLANS directs students to Pick goals, List ways to meet goals, And make Notes, then Sequence notes before writing.

\section{Inquiry Activities}

Inquiry activities help students develop ideas for writing in addition to sharpening their observation, critical thinking, and problem-solving skills (Hillocks, 1982). Inquiry activities typically have a clearly specified goal (e.g., learn about solutions and mixtures in science class), use specific strategies to conduct the analysis (e.g., develop a series of questions to carefully examine the similarities and differences of solutions and mixtures), analyze concrete and immediate data (e.g., examine a number of solutions and mixtures, take notes of observations), and apply what was learned (e.g., write a compare/contrast essay about solutions and mixtures).

Although this instructional method has been validated for use with the range of students found in general education classrooms, research is lacking on its effectiveness with struggling writers (Graham \& Perin, 2007a, 2007b). Nevertheless, they would likely need extensive support throughout the inquiry process. This could include additional modeling; scaffolds such as checklists, prompts, or graphic organizers; and cognitive strategies that support more complex steps in the inquiry activity.

\section{Models of Good Writing}

Highly effective teachers provide good models of the type of writing they expect from students (e.g., Harris et al., 2008). Depending on the type of model needed and the goals for instruction, models can be chosen from authentic text (e.g., children's literature, magazines, poetry, documents), student samples, or teacher-created compositions. Teachers use these models to discuss specific elements or features of the writing with students. The students analyze the models and apply the elements or features in their own writing. Struggling writers will likely have to practice these elements or features extensively before being expected to apply them independently in their own writing. At first, it may be more effective for students to use their developing knowledge while revising their own writing.

Teachers can use models of good writing to teach a number of writing skills. For example, when students are learning to write opinion papers, they could examine effective opinion papers. Teachers draw students' attention to features in the model, such as the use of a topic sentence or supporting details. Students then identify these features in other opinion papers and finally develop a list of features or elements to include in their own writing. Students can apply this list either to a new piece of writing or during the revision phase of previous writing.

Models of good writing can also address lower level writing skills, such as sentence construction. Students can use models to explore how authors or other students construct sentences to convey their intended meaning. Teachers can point out variations in sentence construction across different kinds of writing and audiences. Students then emulate different sentence constructions, working to expand their range of syntactic structures. Finally, students can apply their new knowledge in their own writing during a revision phase. 
Using good models encourages links between reading and writing, a common feature in process approaches to writing. Teaching reading and writing together capitalizes on critical shared knowledge and processes (Fitzgerald \& Shanahan, 2000). For example, struggling writers are less knowledgeable about text structures in different genres (e.g., Englert \& Raphael, 1988; Graham, 1990), which results in lower reading comprehension and poorly organized or incomplete writing. By studying models, they develop an understanding of text structures that can be applied to both reading and writing.

\section{Setting Goals}

The complexity of writing can be overwhelming to many struggling writers, and goal setting helps them target a specific aspect of their writing (e.g., Graham, 2006b). Highly effective writing teachers help struggling writers use specific product goals in focusing their compositions. Previous studies (Ferretti, MacArthur, \& Dowdy, 2000; Graham, MacArthur, \& Schwartz, 1995) highlighted the importance of clear and specific goals (e.g., "add three more pieces of information during revising") as opposed to setting general goals (e.g., "make your paper better").

Goal setting can be used during the initial conception of the paper, during the drafting process, or while revising a draft. Specific product goals should address the purpose of the assignment (e.g., to write a letter to the editor that sways public opinion) and the characteristics of the final composition (e.g., a topic sentence that conveys the writer's opinion, reasons for this opinion, and a concluding sentence). For students who have difficulty getting words on the paper, the teacher can set production goals (e.g., write at least 50 words).

Depending on class needs and the level of mastery, goal setting can be done with a whole group or individually. For example, in a study by De La Paz (1999), middle-school students learned a strategy for writing an expository essay. During the first phases of instruction, the students and teachers collaboratively chose goals that reflected qualities of good writing as well as factors that were emphasized on the statewide writing assessment (e.g., staying on topic, using mature vocabulary, and developing an organized piece of writing). As the students moved toward mastery of the strategies, the teachers evaluated the students' compositions written during independent practice, to set individual goals targeting one or two specific areas of need.

\section{Selection of Thoughtful Writing Activities}

Highly effective teachers are thoughtful about the type of writing tasks they use to engage their students (Boscolo \& Gelati, 2007; Hidi \& Boscolo, 2006). Often, struggling writers are unmotivated, and carefully selected writing activities can represent one step toward motivating them (Pressley et al., 2006). Giving struggling writers the option of choosing tasks that are intellectually and personally engaging may help them develop and maintain the sustained effort necessary for good writing.

A first consideration is the difficulty of the writing task. Assignments that are not intellectually challenging may be boring, while overly difficult tasks can lead to frustration and discouragement (Pressley et al., 2001; Pressley, Mohan, Raphael, \& Fingeret, 2007). Misbehavior during writing activities may be one sign that the writing activity is a mismatch with the student's abilities. Highly effective teachers understand each writer's abilities and adapt assignments accordingly.

Teachers also should consider the purpose of writing activities. Many school writing tasks are for rhetorical exercises or evaluative tools. For example, students frequently complete writing tasks in which the primary purpose is 10 develop, hone, and assess their writing skills. These tasks often do not allow students to set forth their personal ideas, values, points of view, or feelings (Schiwy, 1996; Smith \& Wilhelm, 2002). This can lead to students' viewing academic writing tasks as artificial and demotivating.

Some researchers have argued that authentic literacy activities can increase students' motivation (Bruning \& Horn, 2000; Oldfather, 1993; Oldfather \& Dahl, 1994; Schiwy, 1996; Smith \& Wilhelm, 2002). Although little empirical data are available to support a causal relationship between authentic activities and improved motivation, several hypothesized benefits include allowing students to: (a) express and refine their voice, (b) discover a meaningful purpose by writing for a real audience, (c) develop and adopt a personal writing style by exploring a variety of writing styles, and (d) improve their writing ability by choosing from familiar topics. Students with low interest in writing often prefer control over writing choices and topics (e.g., Flowerday \& Schraw, 2003; Lipstein \& Renninger, 2007; Wade, 2001).

The literature offers several definitions of authentic activities. Generally, teachers are encouraged to select activities that have a clear purpose and real-world relevance and audiences (Bruning \& Horn, 2000; Pressley, Mohan, Raphael, et al., 2007; Smith \& Wilhelm, 2002). Students should have opportunities to select topics that are familiar and personally meaningful (Bruning \& Horn, 2000; Pressley et al., 1997). In addition, writing activities should provide opportunities for collaboration and reflection (Bruning \& Horn, 2000; Pressley et al., 1997; Pritchard \& Honeycutt, 2006, 2007). Collaboration among writers has many benefits. As discussed, it enhances motivation, allows students to learn from each other, and promotes cooperation and inclusiveness among students. Research affirms that struggling writers can be taught how to work together to plan, draft, 
revise, and edit written text effectively (Dailey, 1991; MacArthur, Schwartz, \& Graham, 1991).

\section{Use of Technology}

Highly effective writing teachers use technology to help struggling writers overcome some of their core areas of challenge, such as transcription (Graham \& Perin, 2007a, $2007 \mathrm{~b})$. One purpose of technology is to reduce the burden of difficulties with handwriting and spelling, although technology is useful only if keyboarding or computer skills are automatized; new tools require new skills for students to master. The use of technology has little benefit if students do not receive instruction in how to use the new tool and are not given time to support fluency in using it. Technology supports for transcription skills include word processors and word prediction software.

Substantial research supports the impact of word processing on writing. It can increase both the length and the quality of writing, particularly for struggling writers (BangertDrowns, 1993; Goldberg, Russell, \& Cook, 2003; Graham \& Perin, 2007a, 2007b). One aspect of word processing that can be useful for struggling writers is the spell-check feature, in which poor spellers can be taught how to detect and correct spelling errors. Spell-checkers, however, do have limitations that may reduce their usefulness, especially for students with severe spelling difficulties: Spell-checkers often do not suggest appropriate corrections for the words that are severely misspelled, nor can spell-checkers detect errors in the incorrect use of homonyms. For spell-checkers to be effective, students must receive instruction in how to best use this feature. For example, students might learn the procedural strategy CHECK (Ashton, 1999): Check the beginning of the word; $H$ unt for the correct consonants; Examine the vowels; Changes in suggested words may give hints; Keep repeating previous steps.

Word-prediction software can provide additional support for students who have severe spelling difficulties. As students type in letters, the software suggests a list of possible words from which to choose without having to type the rest of the word. This software is most useful in improving the legibility and spelling of students' written compositions (Handley-More, Deitz, Billingsley, \& Coggins, 2003; MacArthur, 1998, 1999), although one study found that wordprediction software also improved writing quality (Newell, Booth, Arnolt, \& Beattie, 1992).

In addition to transcription support, technology can support planning, drafting, revising, and editing. For example, prompting programs have been shown to assist in the planning and drafting process. Prompting programs ask a set of questions or present reminders as writers progress through various stages of writing. For example, Englert and colleagues developed a web-based prompting program for both narrative and expository writing. The program prompts students to attend to the topical organization and structure of ideas, such as creating a title, topic sentences, details, and a conclusion (e.g., Englert, Wu, \& Zhao, 2005; Englert, Zhao, Dunsmore, Collings, \& Wolbers, 2007). Students who used this program showed improvements in organization and coherence. Finally, word processing can improve students' revising and editing, as it allows students to move sentences and paragraphs easily rather than having to extensively copy over previously written text.

\section{TEACH WRITING STRATEGIES}

Explicitly teaching students how to use writing strategies independently is a highly effective element of writing instruction for all students. The positive effects are particularly robust for students with disabilities and for other struggling writers (Graham \& Harris, 2003; Graham \& Perin, 2007a, 2007b; Rogers \& Graham, 2008). This linding holds true when strategies target generic writing processes such as planning, drafting, revising, or editing, and when strategies are targeted to specific writing tasks such as writing a story, a persuasive essay, or a summary of reading material. Why is writing strategy instruction so effective with such a broad range of students? The reason is most likely that strategies help to simplify and organize the complex tasks required for successful composing (e.g., planning, drafting, and revising) by making the mental processes visible and providing a clearly defined plan for completing a writing assignment successfully (Graham, 2006a, 2006b).

Among the several models of strategy instruction that can be used to improve students' writing, Self-Regulated Strategy Development (SRSD) has been shown to have an especially strong impact (Graham, 2006a; Graham \& Harris, 2003). As an illustration, Graham and Perin's (2007a, $2007 \mathrm{~b})$ meta-analysis revealed that the average weighted effect size for SRSD instruction (1.14) was significantly larger than that resulting from all other non-SRSD interventions (.62); in fact, SRSD yielded a larger effect size than all other instructional approaches combined. Thus, in the remainder of this section, we will focus on SRSD. First we summarize the research base documenting the efficacy and versatility of SRSD. Next we provide an overview of the SRSD model by highlighting its goals, unique features, and instructional stages. Finally, we illustrate the use of SRSD by describing an intervention study consisting of secondgrade struggling writers.

\section{Research Support for SRSD}

For more than 25 years, Harris, Graham, and their colleagues have been involved in the development and evaluation of SRSD. During that time, more than 40 published 
studies have documented that SRSD instruction consistently leads to significant and meaningful improvements in students' writing knowledge, approach to writing (e.g., use of planning and revising strategies), writing performance (i.e., compositional length, completeness, and quality), self-regulation, self-efficacy, and motivation (see Graham, 2006a, 2006b; and Graham \& Harris, 2003, 2005, for detailed reviews and discussions). These gains are typically maintained over time and generalized across settings, genres, and writing media.

Research shows that SRSD is highly versatile, as it has been used successfully in different settings (i.e., one-toone, small groups, and large groups; special and general education classrooms; elementary, middle, and high schools), across varying contexts (e.g., as a separate component of writing instruction and incorporated into Writers' Workshop), with a range of strategies and genres, and with diverse populations, including students with learning disabilities, students with attention deficit hyperactivity disorder, students with behavioral difficulties, struggling writers without identified disabilities, and students who do not have writing difficulties (see Graham, 2006a and Graham \& Harris, 2003 for reviews). After conducting a comprehensive review of the group and single-subject design research evaluating SRSD, Baker, Chard, Ketterlin-Geller, Apichatabutra, and Doabler (2009) determined that it met the Council for Exceptional Children's standards for an evidence-based practice and emphasized that "studies of SRSD in writing represent one of the most consistent efforts to explore the specific features of an instructional intervention, including systematic replications of research", (p. 313).

\section{An Overview of SRSD}

Within the context of writing, SRSD has four overarching goals (Graham \& Harris, 2003):

1. to help students learn and independently apply the same kinds of writing strategies that highly skilled writers use for planning, drafting, revising, and editing their text, and for completing specific compositional tasks, such as persuasive writing;

2. to facilitate students' development of self-regulation procedures that allow for successful management of writing strategies and compositional tasks;

3. to promote students' acquisition of writing knowledge and skills; and

4. to augment students' writing-related motivational dispositions, such as attitude, self-efficacy, and effort.

Although SRSD includes many of the features common to most instructional models, it differs in several important ways, each of which is relevant and critical for struggling writers. First, because struggling writers typically require more intensive and direct instruction than their peers without disabilities, a cornerstone of SRSD is systematic and explicit instruction that targets writing strategies, the accompanying self-regulation procedures, and relevant knowledge. SRSD instruction is scaffolded such that students gradually assume responsibility for applying what they have learned through meaningful models and supported practice opportunities.

Second, the difficulties of struggling writers typically reflect not only cognitive but also affective and behavioral dimensions (Graham \& Harris, 2005). For example, they frequently have difficulty with self-regulation. They also often become entwined in a negative cycle that is fueled by academic failure, self-doubt, learned helplessness, low self-efficacy, maladaptive attributions, unrealistic pre-task expectancies, low motivation, and disengagement. Thus, a fundamental principle of SRSD is the need to intervene directly and repeatedly in ways that serve to develop students' self-regulation, motivation, attitude toward writing, and belief in themselves as capable writers. This is accomplished in several ways, such as targeting the development of self-regulation (e.g., setting goals, using self-instructions, self-monitoring through self-assessment and selfrecording); constructing active and collaborative learning experiences; encouraging teachers to project contagious enthusiasm; and creating supportive, motivating, and affirming classroom environments in which writing is valued and prioritized.

Third, SRSD instruction is individualized to ensure that every student receives instruction that optimizes his or her writing development. Teachers accomplish this by understanding each student's current approach to writing and then differentiating instructional content, process, or both in response to the student's strengths and needs. For instance, teachers might spend more time with a small group of students to develop their relevant background knowledge and skills; modify a strategy for some students to make it more sophisticated; establish individualized writing, self-regulation, and/or affective goals; and/or adjust the nature and frequency of support and feedback.

Fourth, students' progression through SRSD instruction is based on their individual performance and rate of mastery rather than on a preestablished, standardized timetable. Students move through the instructional stages at their own pace, advancing to the next stage only after mastering the criteria for doing so. Students are provided with opportunities to revisit stages if necessary. SRSD instruction does not end until a student demonstrates that he or she can use the targeted strategy and self-regulation procedures independently and effectively. 
Finally, because the ultimate goal of SRSD instruction is for students to incorporate writing strategies and self-regulation procedures into their regular composing routine, techniques to promote maintenance (continuing to use strategies after instruction ends) and generalization (applying strategies to other writing tasks and settings, as appropriate) are integrated throughout the stages of instruction. Some examples include: monitoring students' strategy use over time and offering booster sessions (e.g., mini-lessons to review, discuss, and support strategy use) to those who need them, providing opportunities for students to identify when it would be beneficial to apply the strategies they learned to other tasks and settings and then subsequently reflecting on those experiences, discussing how a strategy could be modified to better align with other tasks and settings, and supporting strategy use through collaboration (e.g., other teachers and school professionals, parents, and peers).

\section{SRSD Instructional Model}

The foundation of SRSD is an instructional framework with six stages (Graham \& Harris, 2005; Harris et al., 2008). Collectively, these stages provide a meta-script, or beginning guideline for instruction, with the intent for them to be reordered, combined, and/or modified in response to students' needs. The states also are recursive, wherein students and teachers revisit or continue aspects of a stage if students did not initially master a concept or component. Although maintaining the integrity of each stage has been shown to significantly impact the extent to which struggling writers benefit from SRSD, students may not always need all six stages. For example, students who already possess robust background knowledge could skip Stage 1 or act as a resource for their peers who will benefit at that stage.

SRSD lessons typically span 20-40 minutes and are implemented 3-5 days a week, depending on grade level and class schedules. Many teachers find that less time than anticipated is necessary to teach students how to use a strategy independently and effectively. In the elementary grades, for example, this goal usually is achieved after 8-12 (30-40 minute) lessons, conducted over a 3- to 5-week period (further details by grade and genre can be found in Graham \& Harris, 2003, 2005).

We next provide a brief overview of each stage. Detailed descriptions of the instructional process and a wide range of strategies, lesson plans, and corresponding materials can be found in Graham and Harris (2005), Harris and Graham (1996), and Harris et al. (2008). A video showing the six stages of instruction in an elementary and a middle school classroom is available from the Association for Supervision and Curriculum Development (2002). Online interactive tutorials about SRSD are available at http://iris.peabody. vanderbilt.edu, and a website devoted to strategy instruction can be found at http://www.unl.edu/csi.

\section{Stage 1: Develop Background Knowledge}

During Stage 1, the primary goal is to ensure that students are adequately prepared to learn and apply the targeted writing strategy and self-regulation procedures. Thus, tcachers first identify what background knowledge and skills are needed, and then assess whether students possess those prerequisites. For example, prior to teaching a story-writing strategy, the teacher determines whether students know basic story-grammar vocabulary (e.g., setting, characters, plot). For some students, the development of background knowledge and skills continues into Stages 2 and 3. At the beginning of Stage 1, many teachers also find it beneficial to help students understand how an internal dialogue can powerfully influence their writing performance.

For instance, when students with disabilities are asked to reflect on what they were thinking or saying to themselves, they often respond, "I hate writing," "I'll never be able to write a good story," or "I can't do this; it's too overwhelming." The negative impact of these statements is discussed and positive alternatives introduced.

\section{Stage 2: Discuss It}

During Stage 2, the teacher and students collaboratively discuss the significance and benefits of the targeted writing strategy and self-regulation procedures, along with when and how they will be used. Each step in the writing strategy is examined, and any corresponding mnemonics are introduced. Two focal points during Stage 2 are (a) enhancing students' motivation and willingness to learn the strategy and (b) developing students' appreciation for the role of effort in learning and using strategies and, in turn, improving writing performance. Within that context, students are asked to make a commitment to be collaborative partners in the SRSD instructional process.

To establish the context and necessity for strategy instruction, teachers often guide students through an examination of their current performance on the targeted composition skill. For instance, if students were learning a persuasive writing strategy, they would examine persuasive essays they wrote previously and graph how many of the necessary elements they included. It cannot be overemphasized, however, that this process of having students examine their pre-SRSD performance must be respectful, collaborative, and encouraging, with emphasis on the positive changes that soon will be realized through learning and using the strategy. This also is a logical point for teachers to introduce the concepts of goal setting and self-monitoring and help each student identify at least one specific, proximal, and appropriately challenging goal (e.g., "Include all seven parts in my story"). 


\section{Stage 3: Model It}

During Stage 3, the teacher models how to use the targeted strategy and self-regulation procedures by thinking aloud as he or she writes an actual composition. Effective modeling does not just happen but, rather, is achieved by attending to several important features.

1. Modeling should be presented in an authentic, enthusiastic, and engaging way.

2. Modeling should include any prompts that will be available for students (e.g., a chart listing the strategy steps, a graphic organizer).

3. Modeling should show students not only how to implement the steps in the writing strategy but also how to effectively utilize the targeted self-regulation procedures.

Thus, a teacher might begin by establishing a goal (or goals) and conclude by self-assessing and self-recording whether the goal was met. Self-instructions that match students' verbal style and language also would be featured prominently throughout the modeling process. For example, a teacher might include self-instructions that relate to problem definition ("What do I have to do to complete this kind of a writing task?", focusing attention and planning ("I need to concentrate. First, I need to..., then I will....”), and/or strategy step statements ("I need to write down my strategy reminder"). Alternatively, the teacher could highlight self-instructions that target self-evaluation and error correcting ("Have I used all my parts? Oops-I missed one so I better add it in!"), coping and self-control ("Stop and breathe! I can do this if I stay calm, try hard, and use my strategy"), and self-reinforcement ("I like this ending! Wow-I worked hard and it paid off!").

After creating the model composition, the teacher and students can benefit from collaboratively exploring questions such as: What were the benefits and challenges associated with the writing strategy and the self-regulation procedures? Do we think the strategy should be modified to be more appropriate or effective?

Finally, students should be offered an opportunity to brainstorm, select, and record personalized self-instructions; frequently these are displayed in the classroom. Because many students need to have a strategy modeled more than once, additional models with the teacher or peers should be provided, as appropriate.

\section{Stage 4: Memorize It}

During Stage 4, students participate in fun, engaging activities to help them memorize the strategy and their personalized self-instructions. Paraphrasing is acceptable as long as it does not compromise the original meaning. Highlighting the rationale for this stage, a student proclaimed,
"You can't use it if you can't remember it!" Students who have difficulty with memorization can be provided with prompts (e.g., cue cards with the strategy steps) and given opportunities to continue to work on memorization through the next stage.

\section{Stage 5: Support It}

During Stage 5 , students gradually assume responsibility for using the writing strategy and self-regulation procedures. This is achieved by providing - and then fading - differentiated levels of support in response to individual students' needs. For example, some students benefit from mini-lessons that target a specific step in the strategy, whereas others may have to see the strategy modeled again either by the teacher or a peer. Students can also support each other by working collaboratively. Throughout this stage, the teacher and students also plan for and initiate generalization and maintenance. Because students vary in the amount of time they require to master the strategy and self-regulation procedures, they progress through this stage at different rates. When the SRSD model is implemented with fidelity, however, most students are able to use a strategy independently and effectively after writing two to four supported compositions.

\section{Stage 6: Independent Performance}

During this stage, students independently use the writing strategy and self-regulation procedures. Collaboratively, teachers and students continue to implement plans for generalization and maintenance (including booster sessions, as needed) and to evaluate efficacy. Students who have not yet transitioned to using their self-statements covertly (i.e., in their head) are encouraged to do so. Other self-regulation procedures (e.g., goal-setting, self-assessment) may be faded over time, as appropriate.

\section{ILLUSTRATIVE EXAMPLE OF SRSD}

Harris, Graham, and Mason (2006) examined the impact of using the SRSD model to teach second-grade struggling writers a general strategy that emphasized planning in advance and two genre-specific strategies designed to help them plan and write stories and persuasive essays. This study was unique in that it targeted students younger than those in previous studies and was designed to investigate whether adding a peer-support component to SRSD instruction would augment the students' performance, especially in terms of maintenance and generalization.

This investigation featured an experimental design; 63 struggling writers from four urban schools were assigned randomly to one of three conditions: SRSD instruction, SRSD instruction plus peer support, or control (the school's Writers' Workshop model). In both SRSD conditions, 
instruction was delivered by trained graduate students and followed the model presented in the previous discussion. Instructors worked with pairs of students three times a week for 20 minutes. On average, students in both SRSD conditions required 6.3 hours of instruction, spanning a period of 9 to 11 weeks, to develop competence with the strategies, knowledge, and skills targeted for story writing. For persuasive writing, they achieved competence after an average of 4.0 hours of instruction over a 6- to 8-week period.

Students in the SRSD conditions first learned a strategy that emphasized planning in advance. This strategy consisted of three steps, represented by the mnemonic POW: Pick my ideas. Organize my notes. Write and say more. Once students were able to use the POW strategy independently, they learned a genre-specific strategy designed to help them carry out the second step of POW within the context of writing a story. This strategy posed seven questions designed to facilitate the generation and organization of ideas for the seven basic parts of a story, represented by the mnemonic WWW, What $=2$, How $=2$ : Who are the main characters? When does the story take place? Where does the story take place? What do the main characters want to do? What happens when the main characters try to do it? How does the story end? How do the main characters feel? For each question, the students learned to make notes on a graphic organizer.

After the students demonstrated that they could use POW and $W W W$, What $=2$, How $=2$ to write stories, they were taught a second genre-specific strategy that would help them carry out the second step of POW within the context of writing persuasive essays. This strategy consisted of four statements designed to facilitate the generation and organization of content relevant to their opinion on a topic, represented by the mnemonic TREE: Tell what you believe. Provide three or more Reasons. End it. Examine. Students generated notes and used a graphic organizer with the prompts in TREE.

Instruction in the SRSD condition was also aimed at students' acquiring critical writing knowledge and self-regulation strategies that would allow them to use the three writing strategies and manage the compositional tasks. For example, the students learned about the purpose of stories and persuasive writing as well as the characteristics and features of exemplary papers in each genre. They learned the importance of using "million dollar words" to make their compositions more interesting, how to "catch the reader," and ways in which transition words can enhance readability for opinion essays. In addition, they learned how to set goals and write complete papers (i.e., to include all the basic elements as well as "million dollar words"), develop and use personalized self-statements, monitor and graph their personal success in achieving these goals, and compare their pre-instructional performance with their performance during instruction. Finally, they learned to credit their success to effort and use of the target strategies.

In the SRSD plus peer support condition, the pairs of students supported each other in using the strategy outside of the instructional situation. Throughout instruction, the two students discussed with the instructor other places or instances where they might use all or some of the strategies they were learning. They also considered whether and how these procedures should be modified for each identified situation. They were encouraged to apply the procedures they were learning to these situations, reminding and helping each other as needed. In subsequent instructional sessions, they each identified when, where, and how they applied the strategy, describing how the strategy helped them to do better and detailing any problems they encountered. They also identified instances in which they helped their partner.

Consistent with previous research, Harris et al. (2006) found that SRSD instruction had a significant and meaningful impact on students' writing knowledge, writing behavior, and writing performance. For example, compared to students in the Writer's Workshop condition, students in the two SRSD conditions were more knowledgeable about how to plan a paper as well as about the basic attributes of both a good story and a persuasive essay. They spent more time planning, and they produced stories and persuasive essays that were longer, more complete, and qualitatively better. These improvements were maintained over time (i.e., 8 weeks after instruction) and generalized to a different setting (i.e., their general education classroom) and two other genres (i.e., personal narrative and informative writing). This study also documented the benefit of adding a peer support component to SRSD instruction, especially with respect to maintenance and generalization.

\section{TEACH WORD-, SENTENCE-, AND PARAGRAPH-LEVEL SKILLS}

Although seemingly less important aspects of writing, the skills of handwriting, spelling, vocabulary, sentence construction, and paragraph writing contribute to overall writing quality. These skills can be seen as the building blocks of proficient writing; students who fail to develop these skills are at risk for writing difficulties (for a review, see Berninger \& Amtmann, 2003; Graham, Harris, \& Fink, 2000; Graham, Harris, \& Fink-Chorzempa, 2002). Struggling writers often have problems with handwriting and spelling (Graham, 1990) and frequently exhibit sentence construction skills that are more simplistic than those of their peers (Scott, 2002). Students with language impairments tend to use fewer unique words than typically developing students do (Nelson \& Van Meter, 2007); their vocabulary is repetitive and less 
precise. As students work to apply their word and sentence abilities to connected text, they often struggle with paragraph construction as well. For example, students with writing difficulties more often include irrelevant details rather than the most important information (e.g., Graham, 1999).

Although teachers have to explicitly and systematically teach word-, sentence-, and paragraph-level skills, studies indicate that the most effective schools and teachers integrate skills instruction within a larger purposeful activity. Many struggling writers need explicit and systematic skills instruction, but it is more effective when teachers help students transfer this knowledge within a broader context of writing. In her study, Langer (2001) summed up her observations in saying, "The pervasive integration of attention to fundamental language skills into the curriculum seemed to make a difference in students' abilities to read, write, and use language well in a variety of situations, including testing” (p. 39).

\section{Handwriting and Spelling}

Previous research has demonstrated that handwriting and spelling play an important role in writing length and writing quality (e.g., Graham et al., 2000, 2002). Unfortunately, the emphasis on writing instruction has shifted away from teaching handwriting and spelling through formal methods, resulting in little support for students who struggle with these skills. Few primary-grade teachers report using a published curriculum for handwriting or spelling instruction (Cutler \& Graham, 2008).

The lack of handwriting and spelling instruction is troublesome, as poor handwriting and spelling ability can have several consequences for students.

1. Writers who must attend to handwriting and spelling have fewer cognitive resources available for thinking about more important aspects of writing, such as idea generation or organization.

2. Poor handwriting and spelling can constrain a writer's development, as students with these difficulties may avoid writing altogether.

3. Compositions with many spelling errors or illegible handwriting may be difficult to read, leading a reader to develop a negative impression of the writer.

4. Slow handwriting reduces productivity, causing problems when students must write under time limits.

Fortunately, research has demonstrated that struggling writers benefit from systematic and explicit instruction in handwriting and spelling. Early intervention for students at risk for handwriting and spelling difficulties can result in improved written compositions and prevent more serious writing disabilities in later years (Graham et al., 2002; see
Berninger \& Amtmann, 2003 for a review). Therefore, highly effective teachers incorporate explicit and systematic handwriting and spelling instruction into their writing program, especially for students who exhibit difficulties with these skills.

Handwriting instruction should be done in short, focused practice sessions. Teachers should show students how to form each letter and point out similarities and differences among letters. Rather than having students write a letter repeatedly, students preferably should be asked to write isolated letlers a few times, identify their best attempt, and then practice the letter in words and sentences. This promotes handwriting fluency, essential for writing productivity. More detailed information about a handwriting program for struggling writers can be found in Graham et al. (2000). This program includes multiple activities addressing letter names, letter formation, and handwriting fluency.

For spelling instruction, teachers should choose spelling words that immediately benefit students. These can include high-frequency words and words from students' own reading and writing. Spelling instruction should emphasize patterns in language. Depending on the students' spelling abilities, language patterns can address phoneme-grapheme correspondences, common rime units, syllable patterns, or morphological units. Students also benefit from pairing reading and spelling instruction. Struggling spellers often have difficulty learning irregular or non-pattern words, so teachers should introduce only a few of these words at a time. Students should also be taught methods for studying spelling words. For example, students can study the letters in each word, visualize and say the letters of the word with closed eyes, restudy the letters, and then write each word three times without looking, while checking and correcting any misspellings. More detailed information about a spelling program for struggling writers can be found in Graham et al. (2002).

\section{Vocabulary}

Selection of vocabulary is considered to be an important part of the writing process. Isaacson (1988) defined vocabulary as the originality and maturity of a student's choice of words and identified it as one of the five principal components that emerge from every major theory of written language. Diverse word usage is one of the most consistent predictors of both narrative and expository writing quality (Olinghouse \& Compton, 2009; Olinghouse \& Leaird, 2009). Little research, however, is available to inform instruction about word choice in writing. The few studies that have explored this topic have found improvements in writing quality by pre-teaching specific words or by having students brainstorm different words in pre-writing activities (Duin \& Graves, 1987; Harris \& Graham, 1985). 


\section{Sentence Construction}

Skilled writers use a variety of different sentence structures in their writing, ranging from simple to more complex syntactic structures. Students with writing difficulties tend to use simplistic or repetitive sentence structures (e.g., "I have a cat. My cat is yellow. My cat is funny"). Traditional grammar instruction has little research support for improving overall writing abilities (e.g., Andrews et al., 2006; see also Graham \& Perin, 2007b, p. 21). For students with disabilities, traditional grammar instruction may improve their grammatical skills, but whether it improves overall writing quality is unknown (Rogers \& Graham, 2008). Research, however, does support two different programs to help students write complete and complex sentences, resulting in better writing quality.

The Sentence Writing Strategy (Schumaker \& Sheldon, 1998) teaches students four sentence structures: simple, compound, complex, and compound-complex. First, the program focuses on simple sentences that contain a subject and a verb with the correct capitalization and ending punctuation. Students also learn metacognitive skills throughout the program, such as monitoring whether sentences make sense.

The sentence-combining approach prompts students to write and rewrite sentences into more syntactically complex sentences. The exercises can be taught in different sequences depending on the students' needs (see Saddler, 2007). Sentence-combining exercises can emphasize skills such as inserting adjectives and adverbs, producing compound subjects and objects, and generating sentences with relative clauses. Instruction typically involves the teacher modeling how to combine two or more sentences into a more complex sentence. Students practice combining similar sentences to produce a similar complex sentence. Students then apply the sentence-combining skill while revising one or more of their papers. The emphasis is on the effectiveness of a sentence within a given context rather than mere correctness.

\section{Paragraphs}

Understanding how to construct a coherent, well-organized paragraph can be difficult for struggling writers. Paragraph writing requires the coordination of word- and sentence-level skills, along with a logical sequence of ideas organized around one main idea. Students with writing difficulties often produce disorganized paragraphs, perhaps because of their inability to integrate multiple skills. Highly effective teachers help students understand how paragraphs are organized by teaching them to use topic sentences, details to support the main idea, and concluding sentences or transitions to the next paragraph. Two different paragraph writing strategies can be found in the literature:
1. In the paragraph writing strategy program (Schumaker \& Lyerla, 1991), students are explicitly taught a strategy to improve their paragraph writing skills, which consists of choosing a topic, organizing and sequencing ideas around the topic, and considering the point of view and verb tense of the paragraph. The strategy also teaches students to use a variety of topic, detail, and ending sentences based on the purpose of the paragraph.

2. The metacognitive strategy strategy PLEASE (Welch, 1992) provides students with several steps to develop a coherent paragraph: Pick your topic, audience, and text format; $L$ ist ideas about your topic; Evaluate your list and plan your organization; Activate the paragraph with a topic sentence; Supply supporting sentences; $E$ nd with a concluding sentence; and Evaluate.

\section{CONCLUDING REMARKS}

Many students-especially students with disabilitieshave difficulty acquiring the competences required for skillful writing (e.g., Graham, 2006b; Graham \& Harris, 2003; Saluhu-Din et al., 2008). As the introductory quotation by Graham and Perin (2007b) emphasized, this should, indeed, be viewed as a crisis. Fortunately, a substantial body of research provides evidence that effective writing instruction can have a significant and meaningful impact on struggling writers' performance. Further, most of the recommendations offered in this article are relevant for all students, not just those who find writing challenging.

We hope that educators will engage in critical reflection that involves the juxtaposition of current writing instruction practices with the approaches we discussed here. In doing this, we anticipate concomitant affirmation (associated with the increased understanding of the research support for instructional methods and routines already being used) and motivation to begin implementing new ideas.

\section{REFERENCES}

Alder, N. (2002). Interpretations of the meaning of care: Creating caring relationships in urban middle school classrooms. Urban Education, 37, 241-266.

Alvermann, D. E. (2003). Exemplary literacy instruction in grades 7-12: What counts and who's counting? In J. Flood \& P. L. Anders (Eds.), Literacy development of students in urban schools: Research and policy (pp. 187-201). Newark, DE: International Reading Association.

Andrews, R., Torgerson, C., Beverton, S., Freeman, A., Locke, T., Low, G., et al. (2006). The effects of grammar teaching on writing development. British Educational Research Journal, 32, 39-55.

Applebee, A., \& Langer, J. (2006). The state of writing instruction in America's schools: What existing data tell us. Retrieved from http://cela.albany.edu 
Ashton, T. M. (1999). Spell CHECKing: Making writing meaningful in the inclusive classroom. Teaching Exceptional Children, 32(2), 24-27.

Association for Supervision and Curriculum Development (Producer). (2002). Teaching students with learning disabilities: Using learning strategies (DVD). Available from http://shop.ascd.org

Baker, S. K., Chard, D. J., Ketterlin-Geller, L. R., Apichatabutra, C., \& Doabler, C. (2009). Teaching writing to at-risk students: The quality of evidence for Self-Regulated Strategy Development. Exceptional Children, 75, 303-318.

Ball, A. F. (2006). Multicultural strategies for education and social change: Carriers of the torch in the United States and South Africa. New York: Teachers College Press.

Bangert-Drowns, R. L. (1993). The word processor as an instructional tool: A meta-analysis of word processing in writing instruction. Review of Educational Research, 63, 69-93.

Bereiter, C., \& Scardamalia, M. (1987). The psychology of written composition. Hillsdale, NJ: Erlbaum.

Berninger, V. W., \& Amtmann, D. (2003). Preventing written expression disabilities through early and continuing assessment and intervention for handwriting and/or spelling problems: Research into practice. In H. L. Swanson, K. R. Harris, \& S. Graham, (Eds.), Handbook of learning disabilities (pp. 345-363). New York: Guilford Press.

Boscolo, P., \& Gelati, C. (2007). Best practices in promoting motivation for writing. In S. Graham, C. A. MacArthur, \& J. Fitzgerald (Eds.), Best practices in writing instruction (pp. 202-221). New York: Guilford Press.

Bruning, R., \& Horn, C. (2000). Developing motivation to write. Educational Psychologist, 35, 25-37.

Cutler, L., \& Graham, S. (2008). Primary grade writing instruction: A national survey. Journal of Educational Psychology, 100, 907-919.

Dailey (1991). The relative efficacy of cooperative learning versus individualized learning on the written performance of adolescent students with writing problems. Unpublished doctoral dissertation, Johns Hopkins University, Baltimore, MD.

De La Paz, S. (1999). Self-regulated strategy instruction in regular education settings: Improving outcomes for students with and without learning disabilities. Learning Disabilities Research \& Practice, 14, 92-106.

Denton, C., Foorman, B., \& Mathes, P. (2003). Schools that "beat the odds": Implications for reading instruction. Remedial and Special Education, 24, 258-261.

Dolezal, S. E., Welsh, L. M., Pressley, M., \& Vincent, M. (2003). How do grade-3 teachers motivate their students? Elementary School Journal, 103, 239-267.

Duin, A. H., \& Graves, M. F. (1987). Intensive vocabulary instruction as a pre-writing technique. Reading Research Quarterly, 22, 311-330.

Englert, C. S., \& Raphael, T. (1988). Constructing well-formed prose: Process, structure and meta-cognitive knowledge. Exceptional Children, 54, 513-520.

Englert, C., Raphael, T., Fear, K., \& Anderson, L. (1988). Students' metacognitive knowledge about how to write informational text. Learning Disability Quarterly, $11,18-46$.

Englert, C. S., Wu, X., \& Zhao, Y. (2005). Cognitive tools for writing: Scaffolding the performance of students through technology. Learning Disabilities Research \& Practice, 20, 184-198.

Englert, C. S., Zhao, Y., Dunsmore, K., Collings, Y., \& Wolbers, K. (2007). Scaffolding the writing of students with disabilities through procedural facilitation: Using an internet-based technology to improve performance. Learning Disability Quarterly, 30 , 9-29.
Ferretti, R. P., MacArthur, C. A., \& Dowdy, N. S. (2000). The effects of an elaborated goal on the persuasive writing of students with learning disabilities and their normally achieving peers. Journal of Educational Psychology, 92, 694-702.

Fitzgerald, J., \& Shanahan, T. (2000). Reading and writing relations and their development. Educational Psychologist, 35, 39-50.

Flowerday, T., \& Schraw, G. (2003). Effect of choice on cognitive and affective engagement. Journal of Educational Research, 96. 207-215.

Freedom Writers \& Gruwell, E. (1999). The Freedom Writers diary: How a teacher and 150 teens used writing to change themselves and the world around them. New York: Broadway Books.

Goldberg, A., Russell, M., \& Cook, A. (2003). The effect of computers on student writing: A meta-analysis of studies from 1992-2002. Journal of Technology, Learning, and Assessment. 2(1), 3-51.

Graham, S. (1990). The role of production factors in learning disabled students' compositions. Journal of Educational Psychology, 82, $781-791$.

Graham, S. (1997). Executive control in the revising of students with learning and writing difficulties. Journal of Educational Psychology, 89, 223-234.

Graham, S. (1999). Handwriting and spelling instruction for students with learning disabilities: A review. Learning Disability Quarterly, $22,78-98$.

Graham, S. (2006a). Strategy instruction and the teaching of writing. In C. MacArthur, S. Graham, \& J. Fitzgerald (Eds.), Handbook of writing research (pp. 187-207). New York: Guilford Press.

Graham, S. (2006b). Writing. In P. Alexander \& P. Winne (Eds.), Handbook of educational psychology (2nd ed., pp. 457-478). Mahwah, NJ: Erlbaum.

Graham, S., \& Harris, K. R. (1997). It can be taught, but it does not develop naturally: Myths and realities in writing instruction. School Psychology Review, 26, 414-424.

Graham, S., \& Harris, K. R. (2003). Students with learning disabilities and the process of writing: A meta-analysis of SRSD studies. In $\mathrm{H}$. L. Swanson, K. R. Harris, \& S. Graham, (Eds.), Handbook of learning disabilities (pp. 323-344). New York: Guilford Press.

Graham, S. \& Harris, K. R. (2005). Writing better. Effective strategies for teaching students with learning difficulties. Baltimore: Brookes.

Graham, S., Harris, K. R., \& Fink, B. (2000). Is handwriting causally related to learning to write? Treatment of handwriting problems in beginning writers. Journal of Educational Psychology, 92 , $620-633$.

Graham, S., Harris, K. R., \& Fink-Chorzempa, B. (2002). Contribution of spelling instruction to the spelling, writing, and reading of poor spellers. Journal of Educational Psychology, 94, 669-686.

Graham, S., Harris, K. R., Fink-Chorzempa, B., \& MacArthur, C. (2003). Primary grade teachers' instructional adaptations for struggling writers: A national survey. Journal of Educational Psychology, 95, 279-292.

Graham, S., Harris, K. R., \& Larsen, L. (200l). Prevention and intervention of writing difficulties for students with learning disabilities. Learning Disabilities Research \& Practice. 16, 74-84.

Graham, S., MacArthur, C. A., \& Schwartz, S. (1995). Effects of goal setting and procedural facilitation on the revising behavior and writing performance of students with writing and learning problems. Journal of Educational Psychology, 87, 230-240.

Graham, S., \& Perin, D. (2007a). A meta-analysis of writing instruction for adolescent students. Journal of Educational Psychology, $99,44.5-476$.

Graham, S., \& Perin, D. (2007b). Writing next: Effective strategies 10 improve writing of adolescents in middle and high schools $\rightarrow A$ 
report to the Carnegie Corporation of New York. Retrieved from http://www.all4ed.org

Graves, A. W., Gersten, R., \& Haager, D. (2004). Literacy instruction in multiple-language first grade classrooms: Linking student outcomes to observed instructional practice. Learning Disabilities Research \& Practice, 19, 262-272.

Handley-More, D., Deitz, J., Billingsley, F. F., \& Coggins, T. E. (2003). Facilitating written work using computer word processing and word prediction. American Journal of Occupational Therapy, 57. 139-151.

Harris, K. R., \& Graham, S. (1985). Improving learning disabled students' composition skills: Self-control strategy training. Learning Disability Quarterly, 8, 27-36.

Harris, K. R., \& Graham, S. (1996). Making the writing process work: Strategies for composition and self-regulation. Cambridge, MA: Brookline Books.

Harris, K. R., Graham, S., \& Mason, L. H. (2006). Improving the writing, knowledge, and motivation of struggling young writers: Effects of self-regulated strategy development with and without peer support. American Educational Research Journal, 43, 295-340.

Harris, K. R., Graham, S., Mason, L. H., \& Friedlander, B. (2008). Powerful writing strategies for all students. Baltimore: Brookes.

Hidi, S., \& Boscolo, P. (2006). Motivation and writing. In C. A. MacArthur, S. Graham, \& J. Fitzgerald (Eds.), Handbosok of writing research (pp. 144-170). New York: Guilford Press.

Hillocks, G. (1982). The interaction of instruction, teacher comment, and revision in teaching the composing process. Research in the Teaching of English, 16, 261-278.

Isaacson, S. (1988). Assessing the writing product: Qualitative and quantitative measures. Exceptional Children, 54, 528-534.

Kiuhara. S. A., Graham, S., \& Hawken, L. S. (2009). Teaching writing to high school students: A national survey. Jourmal of Educational Psychology, 101, 136-160.

Klinger, J., Sorrels, A. M., \& Barrera, M. T. (2007). Considerations when implementing response to intervention with culturally and linguistically diverse students. In D. Haager, J. Klingner, \& S. Vaughn (Eds.), Evidence-based reading practices for response to intervention (pp. 223-244). Baltimore: Brookes.

Langer, J. A. (2001). Succeeding against the odds in English. English Journal, 91, 37-42.

Lenhart, A., Arafeh, S., Smith. A., \& Macgill, A. R. (2008). Writing tec/mology and teens. Retrieved from http://www.pewinternet.org

Lipson, M. Y., Mosenthal, J., Daniels, P., \& Woodside-Jiron, H. (2000). Process writing in the classrooms of eleven fifth-grade teachers with different orientations to teaching and learning. The Elementary School Journal, 101, 209-231.

Lipstein. R. L., \& Renninger, K. A. (2007). "Putting things into words": The development of 12- to 15- year-old students' interest for writing. In S. Hidi \& P. Boscolo (Eds.), Writing and motivation (pp. 113-140). Amsterdam: Elsevier.

MacArthur, C. A. (1998). Word processing with speech synthesis and word prediction: Effects on the dialogue journal writing of students with learning disabilities. Learning Disability Quarterly, 2 l. $151-166$.

MacArthur, C. A., (1999). Word processing with speech synthesis and word prediction: Effects on the dialogue journal writing of students with learning disabilities. Learning Disability Quarterly, 21, 1-16.

MacArthur, C. A.. Schwartz, S., \& Graham, S. (1991). Effects of a reciprocal peer revision strategy in special education classrooms. Learning Disabilities Research \& Practice, 6, 201-210.

Mason. L. H.. Snyder, K. H., Sukhram, D. P., \& Kedem, Y. (2006). TWA + PLANS strategies for expository reading and writing:
Effects for nine fourth-grade students. Exceptional Children, 73, 69-89.

Moates, L., Foorman, B., \& Taylor, P. (2006). How quality of writing instruction impacts high-risk fourth graders' writing. Reading and Writing, 19, 363-391.

Moje, E. B., \& Hinchman, K. (2004). Culturally responsive practices for youth literacy learning. In T. L. Jetton \& J. A. Dole (Eds.), Adolescent literacy research and practice (pp. 321-350). New York: Guilford Press.

Montague, M., \& Rinaldi, C. (2001). Classroom dynamics and children at risk: A follow up. Learning Disability Quarterly, 24. 75-83.

Nelson, N. W., \& Van Meter, A. M. (2007). Measuring written language ability in narrative samples. Reading \& Writing Quarterly. 23, 287-309.

Newell, A. F., Booth, L., Arnott. J., \& Beattie, W. (1992). Increasing literacy levels by the use of linguistic prediction. Child Language Teaching and Therapy, 8, 138-187.

Oldfather, P. (1993). What students say about motivating experiences in a whole language classroom. Reading Teacher, 46, 672-681.

Oldfather, P., \& Dahl, K. (1994). Toward a social constructivist reconceptualization of intrinsic motivation for literacy learning. Jeturnal of Reading Behavior, 26, 139-158.

Olinghouse, N. G., \& Compton, D. L. (2009). Transferring domain knowledge from reading 10 writing in students with reading difficulties. Manuscript in preparation.

Olinghouse, N. E., \& Leaird, J. T. (2009). The relationship between measures of vocabulary and narrative writing quality in secondand fourth-grade students. Reading and Writing, 22, 545-565.

Pajares, F., \& Valiante, G. (2006) Self-efficacy beliefs and motivation in writing development. In C. A. MacArthur, S. Graham, \& J. Fitzgerald (Eds.), Handbook of writing research (pp. 158-170). New York: Guilford Press.

Perin, D. (2007). Best practices in teaching writing to adolescents. In S. Graham, C. A. MacArthur, \& J. Fitzgerald (Eds.), Best practices in writing instruction (pp. 242-264). New York: Guilford Press.

Phillips, N. B., Fuchs, L. S., Fuchs, D., \& Hamlett, C. L. (1996). Instructional variables affecting student achievement: Case studies of two contrasting teachers. Learning Disabilities Research \& Practice, $11,24-33$.

Pressley, M., Gaskins, I. W., Solic, K., \& Collins. S. (2006). A portrait of Benchmark School: How a school produces high achievement in students who previously failed. Journal of Educational Psychology. 98, 282-306.

Pressley, M., Mohan, L., Fingeret, L., Reffitt, K., \& Raphael-Bogaert, L. (2007). Writing instruction in engaging and effective elementary settings. In S. Graham, C. A. MacArthur, \& J. Fitzgerald (Eds.), Best practices in writing instruction (pp. 13-27). New York: Guilford Press.

Pressley, M., Mohan, L., Raphael, L. M., \& Fingeret, L. (2007). How does Bennett Woods Elementary School produce such high reading and writing achievement? Journal of Educational Psychology. 99. 221-240.

Pressley, M., Raphael, L., Gallagher, J. D., \& DiBella, J. (2004). Providence-St. Mel School: How a school that works for African American students works. Journal of Educational Psychology. 96. 216-235.

Pressley, M., Wharton-McDonald, R., Allington, R., Block. C. C., Morrow, L.. Tracey, D., et al (2001). A study of effective grade-I literacy instruction. Scientific Studies of Reading, 5, 35-58.

Pressley, M., Yokoi, L., Rankin, J., Wharton-McDonald, R., \& Mistretta, J. (1997). A survey of the instructional practices of grade 5 
Ebsco Publishing

10 Estes St

Ipswich, MA 01938-2106

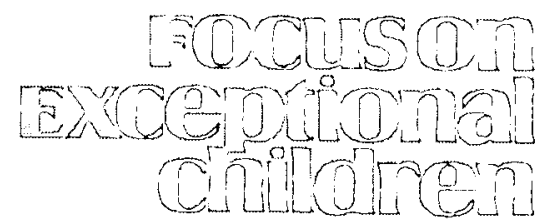

teachers nominated as effective in promoting literacy. Scientific Studies of Reading, 51, 145-160.

Pritchard, R. J., \& Honeycutt, R. L. (2006). Process writing. In C. MacArthur, S. Graham, \& J. Fitzgerald (Eds.), Handbook of writing research (pp. 275-290). New York: Guilford Press.

Pritchard, R. J., \& Honeycutt, R. L. (2007). Best practices in implementing a process approach to teaching writing. In S. Graham, C. A. MacArthur, \& J. Fitzgerald (Eds.), Best practices in writing instruction (pp. 28-49). New York: Guilford Press.

Rankin-Erickson, J. L., \& Pressley, M. (2000). A survey of instructional practices of special education teachers nominated as effective teachers of literacy. Learning Disabilities Research \& Practice, 15, 206-225.

Rogers, L. A., \& Graham, S. (2008). A meta-analysis of single subject design writing intervention research. Journal of Educational Psychology, 100, 879-906.

Saddler, B. (2007). Best practices in implementing a process approach to teaching writing. In S. Graham, C. A. MacArthur, \& J. Fitzgerald (Eds.), Best practices in writing instruction (pp. 163-178). New York: Guilford Press.

Saddler, B., \& Graham, S. (2007). The relationship between writing knowledge and writing performance among more and less skilled writers. Reading \& Writing Quarterly, 23, 231-247.

Salahu-Din, D., Persky, H., \& Miller, J. (2008). The nation's report card: Writing 2007. Retrieved from http://nces.ed.gov

Sandmel, K, \& Graham, S. (2009, February). A meta-analysis of the effects of process writing instruction. Poster presented at Pacific Coast Research Conference, Coronado, CA.

Schiwy, M. A., (1996). Voice of her own: Women and the journal writing journey. New York: Fireside.

Schultz, K. (2002). Looking across space and time: Reconceptualizing literacy learning in and out of school. Research in the Teaching of English, 36, 356-380.

Schumaker, J. B., \& Deshler, D. D. (1992). Validation of learning strategy interventions for students with learning disabilities: Results of a programmatic research effort. In Y. Y. L. Wong (Ed.), Contemporary intervention research in learning disabilities: An international perspective (pp. 22-46). New York: Springer-Verlag.

Schumaker, J. B., \& Lyerla, K. D. (1991). The Paragraph Writing Strategy. Lawrence: University of Kansas Center for Research on Learning.

Schumaker, J. B., \& Sheldon, J. (1998). The Sentence Writing Strategy. Lawrence: University of Kansas Center for Research on Learning.
Scott, C. M. (2002). A fork in the road less traveled: Writing intervention based on language profile. In K. G. Butler \& E. R. Silliman (Eds.), Speaking, reading, and writing in children with language learning disabilities: New paradigms in research and practice (pp. 219-237). Mahwah, NJ: Erlbaum.

Smith, M. W., \& Wilhelm, J. D. (2002). "Reading don't fix no Chevys": Literacy in the lives of young men. Portsmouth, NH: Heinemann.

Stuhlman, M. W., \& Pianta, R. C. (2009). Profiles of educational quality in first grade. The Elementary School Journal, 109, 323-342.

Tatum, B. D. (2008). Can we talk about race? and other conversations in an era school resegregation. Boston: Beacon Press.

Taylor, B. M., Pearson, P. D., Clark, K., \& Walpole, S. (2000). Effective schools and accomplished teachers: Lessons about primarygrade reading instruction in low-income schools. The Elementary School Journal, 101, 121-165.

Troia, G. A., Lin, S. C., Monroe, B. W., \& Cohen, S. (2009). The effects of Writing Workshop instruction on the performance and motivation of good and poor writers. In G. A. Troia (Ed.), Instruction and assessment for struggling writers: Evidence-based practices (pp. 77-112). New York: Guilford Press.

Vaughn, S., Gersten, R., \& Chard, D. J. (2000). The underlying message in LD intervention research: Findings from research syntheses. Exceptional Children, 67, 99-114.

Villegas, A. M., \& Lucas, T. (2002). Preparing culturally responsive teachers: Rethinking the curriculum. Journal of Teacher Education, 53, 20-32.

Wade, S. E. (2001). Research on importance and interest: Implications for curriculum development and future research. Educational Psychology Review, 13, 243-261.

Welch, M. (1992). The PLEASE strategy: A metacognitive leaming strategy for improving the paragraph writing of students with mild learning disabilities. Learning Disability Quarterly, 15, 119-128.

Wong, B. Y. L., Butler, D. L., Ficzere, S. A., \& Kuperis, S. (1996). Teaching low achievers and students with learning disabilities to plan, write, and revise opinion essays. Journal of Learning Disabilities, 29, 197-212.

Wong, B. Y. L., Butler, D. L., Ficzere, S. A., \& Kuperis, S. (1997). Teaching adolescents with learning disabilities and low achievers to plan, write, and revise compare-and-contrast essays. Learning Disabilities Research \& Practice, 12, 2-15.

\section{PERMISSIONS AND COPYRIGHT}

All rights are reserved. No part of this publication may be reproduced, photocopied, faxed, stored in a retrieval system, or transmitted in any form or by any means, electronic, mechanical, recording or otherwise, without the prior written permission of the publisher.
Back issues are available for sale. Reproduction requires permission and payment of fees. It is illegal and a violation of federal copyright law to reproduce this publication without permission. Direct all inquiries to the permissions editor. 
Copyright of Focus on Exceptional Children is the property of Love Publishing Company and its content may not be copied or emailed to multiple sites or posted to a listserv without the copyright holder's express written permission. However, users may print, download, or email articles for individual use. 